\title{
MET Kinase Inhibitor OMO-1
}

National Cancer Institute

\section{Source}

National Cancer Institute. MET Kinase Inhibitor OMO-1. NCI Thesaurus. Code C148537.

An inhibitor of the proto-oncogene and receptor tyrosine kinase (RTK) hepatocyte growth factor receptor (c-Met; HGFR; MET) with potential antineoplastic activity. Upon administration, OMO-1 selectively binds to c-Met, thereby inhibiting c-Met phosphorylation and disrupting c-Met signal transduction pathways. This may induce cell death in tumor cells overexpressing c-Met protein or expressing constitutively activated c-Met protein. c-Met, a receptor tyrosine kinase overexpressed or mutated in many tumor cell types, plays key roles in tumor cell proliferation, survival, invasion, metastasis, and tumor angiogenesis. 